\title{
Combination Effects of Self-Volar Gliding Using a Strap and Wrist Distraction on Pain and Wrist Extension Range of Motion in Subjects with Dorsal Wrist Pain
}

\author{
Ki-Song Kim, and In-Cheol Jeon
}

Department of Physical Therapy, College of Life and Health Science, Hoseo University, Research Institute for Basic Sciences, Hoseo University, Asan, Korea

Purpose: This study examined the effects of self-volar gliding combined with a strap and wrist distraction on pain and the active and passive wrist extension range of motion (ROM) in subjects with dorsal wrist pain during partial weight bearing of the hand.

Methods: Thirty subjects (14 males and 16 females) with dorsal wrist pain during partial weight bearing through the hand participated in this study. The two different self-volar gliding techniques were performed for each group. Self-volar gliding using a strap (SVGS) and SVGS and wrist distraction (SVGSD) were performed five times for one week for each group. The active and passive ROM of wrist extension and the peak pressure pushed by the hand at pain (PPHP) were measured. An independent t-test was used to compare the improvements of these elements between the two different self-volar gliding techniques. The level of statistical significance was at $\alpha=0.05$.

Results: The active and passive ROM of wrist extension and PPHP were greater in both self-volar gliding groups after the one week intervention. On the other hand, these parameters were greater in the SVGSD group than in the SVGS group $(p<0.05)$

Conclusion: SVGSD is recommended to improve the active and passive ROM of wrist extension and PPHP in subjects with dorsal wrist pain during partial weight bearing of the hand.

Keywords: Dorsal wrist pain, Self-volar gliding, Wrist distraction

\section{서 론}

손목관절의 바닥 쪽 활주(volar gliding)는 손목관절의 폄 증가를 위 해 필수적이다.1,2 손목뼈에 바닥 쪽 활주가 불충분하다면, 손목관절 폄은 제한과 통증이 생긴다. ${ }^{1,2}$ 손목벼의 해부학적 구조를 볼 때, 가까 운 쪽 부위(proximal carpal row)는 손배뼈(scaphoid bone), 반달뼈(lunate bone), 세모뼈(triquetrum bone) 그리고 콩알뼈(pisiform bone)로 구 성되어 있고, 아래팔의 먼쪽 부위에서는 노뼈(radius)와 자뼈(ulnar)로 구성되어 있다. ${ }^{2}$ 하지만 손과 아래팔 쪽에서 대부분의 손목 부위를 직접적으로 접촉하여 관절을 구성하는 뼈는 손배뼈(scaphoid bone) 와 반달뼈(lunate bone) 그리고 먼쪽 노뼈(distal radius)라고 할 수 있 다. ${ }^{2,3}$ 만약 손목관절에서 열린사슬운동으로 폄을 수행한다면, 손목 뼈의 손배뼈와 반달뼈는 볼록관절(convex joint)을 형성하기 때문에 굴림(rolling)은 등 쪽(dorsal side)으로 일어나고, 활주는 바닥 쪽으로

Received Sep 4, 2019 Revised Oct 21, 2109

Accepted Oct 22, 2019

Corresponding author In-Cheol Jeon

E-mail jeon6984@hoseo.edu
일어난다. ${ }^{2,4}$ 반면에 닫힌사슬운동으로 폄을 수행한다면, 오목관절 (concave joint)을 형성하고 있는 먼 쪽 노뼈는 굴림과 활주가 모두 등 쪽으로 일어난다. 만약 손목관절을 감싸고 있는 관절주머니(joint capsule)에 탄력성(flexibility)이 부족하다면 손배뼈와 반달뼈의 바닥 쪽 활주는 제한이 생기게 된다. 손목관절 폄 각도가 증가됨에 따라서 손목관절 내부에서는 굴림과 활주가 더 많이 필요하게 되는데, 관절 주머니 내부에서 더 큰 공간이 확보되지 않으면, 필요한 만큼의 굴림 과 활주가 일어나지 않기 때문이다. 이 제한은 결국 관절각도 제한을 야기시키고, 손목관절 내부의 압력 증가로 인해서 통증을 유발시키 게 된다. 따라서 이때 손목뼈의 적절한 활주를 적용하여 관절주머니 의 탄력성을 증가시켜 준다면, 손목관절 폄을 수행하는 데 효과적이 고, 통증 없이 정상 움직임을 만들 수가 있다.1,2,

등 쪽 손목 통증(dorsal wrist pain)은 손을 많이 사용하는 직업을 가 진 대상자에게서 발생하는 대표적 질환 중에 하나이다. 등 쪽 손목 통 
증은 손목에 부하가 걸린 채로 손목관절 폄을 반복적으로 하는 사람 들에게 더 빈번하게 발생한다.5.6 손바닥을 과도하게 뒤로 젖히거나 손 바닥을 통해서 체중이 지지되는 동안에, 손목뼈를 구성하는 손배뼈와 반달뼈에서 바닥 쪽활주가 적절하게 일어나지 않으면, 먼 쪽 노뼈 사이 에서 압력이 증가하게 되고, 이것은 곧 통증을 유발하게 된다.2,7.8 이러 한 통증은 특히 손배뼈 충돌 증후군(scaphoid impaction syndrome)이 있는 대상자에게 부하가 생겼을 때 더 증가되는 경향을 보였다.69

손목관절에 통증이 유발되는 경우, 통증을 줄이기 위해서 비스테 로이드성 항염제를 사용하거나, 스플린트와 같이 손목의 움직임을 제한하는 방법을 사용해왔다. ${ }^{69}$ 또한 관절 가동화나 손목근육 신장 운동 등을 손목관절의 가동성과 기능을 향상시키기 위해 사용해왔 다.10-12 관절가동화를 적용하기 위해 일반적으로 손목관절을 열린사 슬운동으로 수행하는데, 열린사슬운동 자세에서도 손목관절의 움 직임 범위가 증가되는 장점이 있었다. ${ }^{12}$ 또한, 닫힌사슬운동 자세에서 수행한 이전 연구에서는 손목관절 폄 각도에 제한이 있고, 손목관절 등 쪽 통증이 있는 대상자에게 스트랩을 이용해서 바닥 쪽 활주를 1 주일간 적용하였더니, 수동적 그리고 능동적 손목관절 폄 각도가 향 상되었고, 손바닥으로 체중을 지지한 상태에서 발생하는 통증이 감 소되었다고 보고하였다. ${ }^{8}$

능동적 그리고 수동적 손목관절 폄 각도가 제한이 있고, 손바닥을 통해 체중을 지지했을 때 통증이 유발되는 대상자에게 손으로 체중 지지를 하였을 때, 손목뼈 움직임을 향상시키는 것이 중요하다. 손목 관절의 폄 각도에 제한이 크거나, 손으로 체중 지지 시 큰 통증을 느 끼는 대상자들을 위해서 이 연구에서는 기존 연구에서 적용된 방법 보다 더 효과적인 운동법을 고안하고자 하였다. 이전 연구에서는 체 중을 지지한 상태에서 반대쪽 손으로 스트랩을 이용해서 손목관절 에 바닥 쪽 활주(self-volar gliding using a strap, SVGS)를 적용하였지만, 이 연구에서는 손목관절에 신연(wrist distraction)을 병행하면서 바닥 쪽 활주의 적용(self-volar gliding using a strap and wrist distraction, SVGSD)과 기존 적용법과의 효과를 비교하고자 하는 것이 목적이다.

\section{연구 방법}

\section{1. 연구대상}

이 연구에서는 능동적 그리고 수동적 손목관절 폄 제한과 손을 통해 체중지지를 하였을 때 손목관절 부위에 통증이 있는 대상자 30 명(남자 14 명, 여자 16명)이 참여했다. 실험 대상자들은 전부 대학생으로 구성되 어 있으며, 손목 통증을 위해서 병원 치료를 받은 경험이 없었다. 실험 대상자들의 평균 나이는 21.6 \pm 7.5 세(SVGS 그룹), $22.5 \pm 6.7$ 세 (SVGSD 그 룹)이었고, 평균체중은 $65.4 \pm 6.3 \mathrm{~kg}$ (SVGS 그룹), $66.2 \pm 5.2 \mathrm{~kg}$ (SVGSD 그 룹)이었고, 평균 신장은 $170.1 \pm 4.7 \mathrm{~cm}$ (SVGS 그룹), $171.4 \pm 4.3 \mathrm{~cm}$ (SVGSD
그룹)이었다 $(\mathrm{p}>0.05)$. 대상자들은 손바닥으로 체중을 지지하였을 때 두 달 이상 손등의 통증을 호소하였다. 대상자들은 손목 관절에 수술 전력, 골절 또는 신경학적 문제가 있는 경우에는 제외되었다. 또한 연골, 인대에 손상이 있는 경우와 손목 결절이 있는 경우 실험에서 제외되었 다. 연구를 시작하기 앞서, 모든 과정을 대상자에게 설명하였으며 대상 자는 미리 작성된 동의서에 모두 서명하였다.

\section{2. 실험방법}

1) 실험절차

손목관절 폄 각도 측정은 측정 편향(measurement bias)을 최소화시키 기 위해 근골격계 손상의 관절가동범위와 통증 측정에 경험이 있는 물리치료사가 수행하였다. 손목관절 폄 각도의 능동적 그리고 수동 적 가동범위와손을 통해 체중 지지를 했을 때 통증이 유발되는 최대 압력 그리고 손목관절에서 생기는 시각통증척도를 활주 적용 전후 로 측정하였다. 각각의 측정은 세 번씩 측정한 후 평균값을 계산하였 다. 측정자는 스트랩을 이용한 기법에 대해서 자세하게 설명해 주고, 시범을 보여줬고, 재현할 수 있도록 교육했다. 일반적인 운동화끈(길 이: $125 \mathrm{~cm}$, 폭: $1 \mathrm{~cm}$ )을 이용해서 손을 통해서 부분적으로 체중 지지 를 하면서 손목관절을 폄을 했을 때 손목뼈에 활주를 적용하였다.

(1) 능동적 그리고 수동적 손목관절 폄 각도

각도계를 사용하여 능동적 그리고 수동적 손목관절 폄 각도를 측정 하였다. 통증이 없는 상태에서 손목관절이 최대로 폄 자세를 취하였 을 때, 5 번째 손허리관절뼈와 노뼈 사이의 각도를 측정하였다. 대상자 는 선 자세에서 팔꿈치를 펴고 어깨 굽힘 $90^{\circ}$ 각도에서 능동적 그리 고수동적 손목관절 폄 각도를 취하게 했다. 대상자는 통증이 느껴지 지 않는 범위 내에서 능동적으로 손목관절 폄을 최대한 수행했다. 수 동적 손목 관절 폄 각도를 측정하기 위해서 다른 손을 이용해서 수동 적으로 한쪽 손목을 폄을 유지하게 했다. 손목관절 폄 자세가 최대한 진행되었을 때, 측정자는수동적 손목관절 폄 각도를 측정했다.

\section{(2) 통증이 유발되는 최대압력(peak pressure pushed by the hand at pain, PPHP)}

손을 통해서 체중을 지지하는 동안 통증이 유발되는 최대압력을 측 정하기 위해서 도수근력측정기(hand-held dynamometer, Lafayette Instrument Company, USA)를 사용하였다. 측정 전에 도수근력측정기 를 표준화(normalizaion)시켰다. 손바닥으로 누르는 압력을 측정하기 위해 손바닥과 접촉이 되는 도수근력 측정기를 측정테이블에 위치 시키고, 손으로 도수근력측정기를 중력 방향으로 최대한 눌렀다. 손 을 통해서 체중 지지를 수행했을 때 손목관절의 손등에 통증이 유발 되는 시점에서 발생되는 최대 압력 $(\mathrm{kg})$ 을 기록하였다. 
(3) 시각통증척도(visual analogue scale, VAS)

시각통증척도를 이용해서 손목관절의 통증을 측정하였다. 시각통증 척도는 $10 \mathrm{~cm}$ 길이의 자 형태를 하고 있고, 왼쪽 끝은 $0 \mathrm{~cm}$ 에서 시작해 서 통증이 없는 것을 의미하고, 오른쪽 끝은 $10 \mathrm{~cm}$ 에서 끝나고 극심한 통증으로 설명될 수 있다. 모든 대상자는 손을 통해서 체중을 지지하 는 동안 통증의 강도에 따라 시각통증척도를 표시를 하였다.10,13

\section{2) 스트랩을 이용한 바닥 쪽 활주(self-volar gliding using a strap, SVGS)}

대상자는 치료테이블 앞에 섰다. 손목관절을 중립 자세에서 정렬을 잘 맞춘 상태에서 어깨관절과 팔꿈치 관절은 편안한 자세를 유지한 채, 치료용 테이블 모서리에 통증이 있는 손목관절을 위치시켰다. 먼 쪽 자뼈 끝 바로 밑과, 손배뼈 사이의 손등부위 중앙에 스트랩을 위 치시켰다. 통증 없이 손배뼈를 서서히 중력 방향(volar gliding)으로 활 주를 시켜주기 위해서 반대쪽 손을 이용해서 스트랩을 바닥 쪽으로 당겨줬다. 손목관절 폄을 증가시키기 위해서 스쿼트 자세에서 서서 히 선 자세를 취하면서, 손목관절의 폄을 수행하였다. 반대쪽 손을 통
해서 중력방향으로 당기면서, 팔목관절의 치료면에 수평으로 스트랩 을 유지시켜주면서 계속 적용했다(Figure 1). 대상자는 스트랩을 이용 한 바닥 쪽 활주 마지막 자세에서 10 초씩 유지하는 것을 10 번 반복하 였고, 매 사이 20 초간의 휴식시간을 주었다. 대상자가 스트랩을 이용 한 바닥 쪽 활주를 정확하고 적절하게 적용하기 위해서 전체적인 과 정을 측정자가 관찰하도록 했다. 1 주일간 5 번의 세션을 수행하는 동 안, 능동적 그리고 수동적 손목관절 폄과 통증이 유발되는 최대압력 과 시각통증척도를 평가했다. 데이터 처리를 위해서 3 번의 결괏값을 평균냈고, 활주 적용 전 측정과 1 주 적용한 이후 측정을 시행하였다. 모든 측정은 독립된 측정자에 의해 시행되었다.

\section{3) 자가 신연이 적용된 상태에서 스트랩을 이용한 바닥 쪽 활주(self-} volar gliding using a strap and wrist distraction, SVGSD) 일반적인 운동화끈 한 쌍을 하나로 연결한 스트랩을 치료용 테이블 의 높이보다 $3 \mathrm{~cm}$ 짧게 맞췄다. 치료용 테이블 앞에서 자뼈 먼 쪽 끝 바로 밑과, 손배뼈 사이의 손등부위 중앙에 위치시킨 스트랩을 한쪽 발을 발등굽힘(dorsiflexion)한 채로 고정해 줬다. 대상자는 반대쪽 손
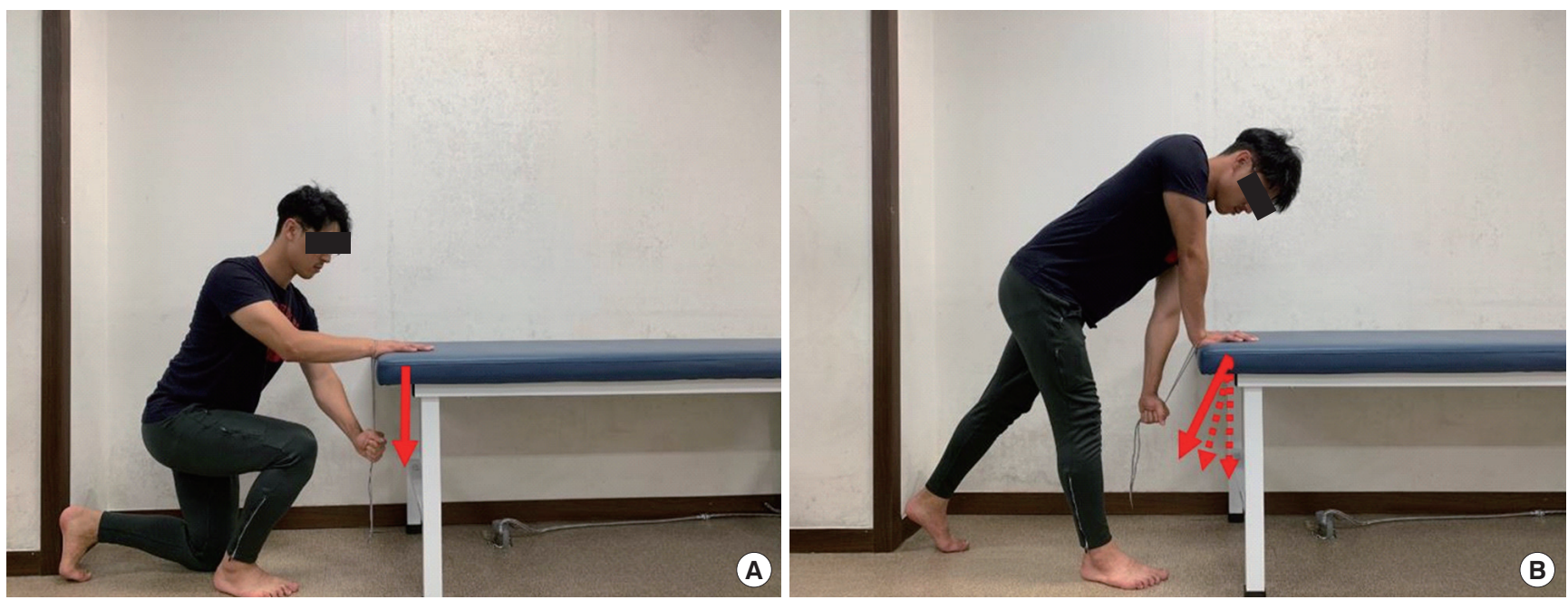

Figure 1. The self-volar gliding using a strap. (A) Starting position. (B) End position.
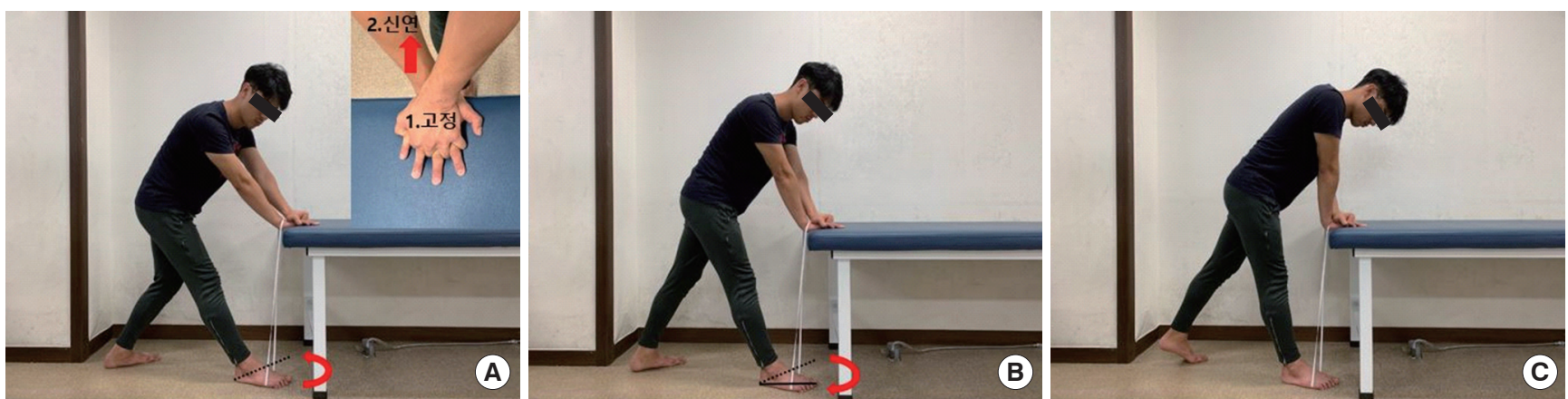

Figure 2. The self-volar gliding using a strap with wrist distraction. (A) Starting position. (B) Mid position. (C) End position. 
을 이용해서 해당 손을 깍지 낀 채로 신연 level 1 을 적용했다. 이 연구 에서의 신연의 적용은 단순히 관절 사이를 분리 또는 당겨서 떼어놓 는다는 것으로 정의했다. 이 상태를 유지한 채로 발등 굽힘한 발을 서 서히 내려주면서 스트랩에서 바닥 쪽 활주가 잘 일어나게 해줬다. 발 쪽에 중립자세로 유지되면서 당겨지는 힘과 반대손으로 신연해 주 는 힘을 유지하면서, 손목관절을 서서히 $90^{\circ}$ 까지 폈다. 손목관절 폄 이 $90^{\circ}$ 각도에서 손바닥이 테이블로부터 떨어지지 않도록 밀착된 상 태를 유지했다(Figure 2). 통증이나, 불편함이 유발되지 않는 강도 안 에서 스트랩을 고정한 발은 중립위치에서 그대로 유지했고, 바닥 쪽 활주 적용을 10 초씩 10 번을 적용하였다. 사이에 20 초 휴식시간을 가 졌다. 1 주일간 5 번 적용하였다. 그 외 나머지 과정은 스트랩을 이용한 활주 기법과 동일하게 적용하였다.

\section{4) 통계분석}

모든 데이터는 SPSS software (ver. 18.0, SPSS Inc., Chicago, IL, USA)를 통해서 분석하였다. 일표본 Kolmogorov-Smirnov 검정을 통해 측정데 이터의 정규 분포를 확인하였다. 바닥 쪽 활주의 효과를 확인하기 위
해서 Cohen d 값을 이용해서 계산하였다. ${ }^{14}$ Cohen d 값은 0.8 초과는 강한 효과-(strong effect), 0.4 초과 0.8 이하는 중간 효과(moderate effect), 0.4 이하는 약한 효과(weak effect)를 가리킨다. ${ }^{14}$ Independent t-test 를 사용하여 SVGS 그룹과 SVGSD 그룹 사이의 초기 손목관절 폄 각 도를 비교하였다. Paired t-test를 사용하여 두 그룹 사이의 활주 적용 전과 적용 후의 종속변수를 비교하였다. 두 그룹 간에 초기값이 서로 달랐기 때문에, 공변량(covariates)을 사용하여 두 그룹 간에 종속변 수를 비교하고자 analysis of covariance (ANCOVA)를 사용했다. Mann-Whitney test를 사용하여 두 그룹 사이의 시각통증척도를 통한 통증점수를 비교하였다. 통계학적 유의 수준은 0.05 로 정했다.

\section{결 과}

SVGS 그룹과 SVGSD 그룹에서 활주를 적용하기 전에 비해서 1주일 간 활주를 적용한 후에 능동적 그리고 수동적 손목관절 폄 각도와 통증이 유발되는 최대압력에 통계학적 유의한 증가를 보였다(Table $1,2)(\mathrm{p}<0.05)$. 또한 시각통증척도에서도 SVGS 그룹과 SVGSD 그룹에

Table 1. Pre and Post-intervention active and passive range of motion of wrist extension in the volar gliding groups

(unit: ${ }^{\circ}$ )

\begin{tabular}{|c|c|c|c|c|c|c|c|}
\hline \multirow{2}{*}{\multicolumn{2}{|c|}{ Intervention group }} & \multicolumn{2}{|c|}{ Mean $\pm S D$} & \multirow{3}{*}{$\begin{array}{c}\text { Mean difference } \\
10.92\end{array}$} & \multirow{3}{*}{$\begin{array}{c}\text { t-value } \\
-4.84\end{array}$} & \multirow{3}{*}{$\begin{array}{c}\text { p-value } \\
<0.05^{*}\end{array}$} & \multirow{3}{*}{$\begin{array}{c}\text { Effect Size } \\
0.83\end{array}$} \\
\hline & & \multirow{2}{*}{$\begin{array}{c}\text { Pre } \\
36.63 \pm 8.44\end{array}$} & \multirow{2}{*}{$\begin{array}{c}\text { Post } \\
47.55 \pm 7.82\end{array}$} & & & & \\
\hline AROM & SVGS & & & & & & \\
\hline & SVGSD & $34.51 \pm 5.93$ & $47.92 \pm 8.57$ & 13.41 & -6.52 & $<0.05^{*}$ & 0.91 \\
\hline \multirow[t]{2}{*}{ PROM } & SVGS & $55.43 \pm 10.81$ & $68.21 \pm 12.3$ & 12.78 & -4.67 & $<0.05^{*}$ & 0.85 \\
\hline & SVGSD & $53.72 \pm 9.43$ & $69.57 \pm 7.93$ & 15.85 & -7.98 & $<0.05^{*}$ & 0.94 \\
\hline
\end{tabular}

AROM: active range of motion, PROM: passive range of motion, SD: standard deviation, SVGS: the self-volar gliding using a strap, SVGSD: the self-volar gliding using a strap with wrist distraction. *Independent t-test: $p<0.05$.

Table 2. Pre and Post-intervention the peak pressure pushed by the hand at pain in the volar gliding groups

(unit: kg)

\begin{tabular}{|c|c|c|c|c|c|c|}
\hline \multirow{2}{*}{ Intervention group } & \multicolumn{2}{|c|}{ Mean \pm SD } & \multirow{2}{*}{ Mean difference } & \multirow{2}{*}{ t-value } & \multirow{2}{*}{$\mathrm{p}$-value } & \multirow{2}{*}{ Effect Size } \\
\hline & Pre & Post & & & & \\
\hline SVGS & $15.14 \pm 4.42$ & $24.56 \pm 5.14$ & 9.42 & -14.1 & $<0.05^{*}$ & 0.87 \\
\hline SVGSD & $15.61 \pm 3.92$ & $28.16 \pm 6.49$ & 12.55 & -17.2 & $<0.05^{*}$ & 0.97 \\
\hline
\end{tabular}

SD: standard deviation, SVGS: the self-volar gliding using a strap, SVGSD: the self-volar gliding using a strap with wrist distraction. *Independent t-test: $p<0.05$.

Table 3. Post-intervention analysis of covariance results

\begin{tabular}{|c|c|c|c|c|c|c|}
\hline \multirow{2}{*}{ Variable } & \multirow{2}{*}{ Covariate } & \multicolumn{2}{|c|}{ Mean $(95 \% \mathrm{Cl})$} & \multirow{2}{*}{ Adjusted $\mathrm{R}^{2}$} & \multirow{2}{*}{ F-value } & \multirow{2}{*}{$\mathrm{p}$-value } \\
\hline & & SVGS & SVGSD & & & \\
\hline \multirow[t]{2}{*}{ AROM } & 35.49 & $46.89 \pm 6.15$ & $48.64 \pm 4.29$ & 0.50 & -6.94 & $<0.05^{*}$ \\
\hline & & (45.75-47.94) & $(47.98 \pm 49.76)$ & & & \\
\hline \multirow[t]{2}{*}{ PROM } & 54.51 & $67.31 \pm 5.97$ & $70.47 \pm 6.21$ & 0.69 & -12.94 & $<0.05^{*}$ \\
\hline & & $(66.14-68.52)$ & $(69.31-72.14)$ & & & \\
\hline \multirow[t]{2}{*}{ PPHP } & 15.34 & $24.31 \pm 6.79$ & $28.42 \pm 4.94$ & 0.61 & -9.82 & $<0.05^{*}$ \\
\hline & & $(23.21 \pm 26.29)$ & (26.81-29.53) & & & \\
\hline
\end{tabular}

AROM: active range of motion, PROM: passive range of motion, SD: standard deviation, PPHP: peak pressure pushed by the hand at pain, Cl: confidence interval, SVGS: the self-volar gliding using a strap, SVGSD: the self-volar gliding using a strap with wrist distraction. ${ }^{*}$ Independent t-test: $p<0.05$. 
서 모두 활주를 적용하기 전에 비해서 1 주일간 활주를 적용한 후에 통계학적 유의한 감소를 보였다.

두 그룹을 공변량으로 비교했을 때, 능동적 그리고 수동적 손목관절 폄 각도 그리고 통증이 유발되는 최대압력에서 SVGSD 그룹이 SVGS 그 룹에 비해서 통계학적 유의한 증가를 보였다(Table 3)(p<0.05). 시각통 증척도에서도 SVGSD 그룹이 SVGS 그룹에 비해서 통계학적 유의한 감소를 보였다 $(2.9 \pm 0.5,3.1 \pm 0.4)(\mathrm{p}<0.05)$.

\section{고 찰}

손목관절 폄의 각도를 증가시키기 위해서 손목뼈의 바닥 쪽 활주는 아주 중요한 요소이고, 손목 움직임을 동반한 바깥쪽 활주가 손목관 절의 손상을 향상시킬 수 있다.1015,16 이 연구에서는 1 주일간 5 번의 활 주를 적용하였을 때, SVGSD 그룹이 SVGS 그룹에 비해서 능동적 그 리고 수동적 손목관절 폄 각도와 통증이 유발되는 최대압력에 통계 학적으로 유의한 증가를 보였다. 또한 시각통증척도에서도 통계학적 으로 유의한 감소를 보였다. 선행연구에서는 손목관절에 제한이 있 거나, 손목 폄 각도가 $50^{\circ}$ 이상 펴지지 않으면서 통증이 증가되는 대 상자에게 도수를 이용해서 손목뼈에 바닥 쪽 활주를 5 세션 적용하였 더니 폄 각도가 $50^{\circ}$ 에서 $66.7^{\circ}$ 까지 증가되고, 통증이 감소됨을 보였 다. ${ }^{15}$ 다른 연구에서는 4 주간 8 번의 적용을 통해서 노뼈 쪽 손목관절 가동화 기법(앞쪽 뒤쪽 활주와 자뼈쪽 활주)이 디쿼바리안 병(de Quervain's disease)을 가진 대상자의 통증을 감소시키고 기능을 향상 시켰다. ${ }^{11}$ 또한 스트랩을 이용한 바닥 쪽 활주를 1 주일간 5번 적용하 였을 때 능동적 그리고 수동적 손목관절 폄 각도와 통증이 유발되는 최대압력의 유의한 증가를 가져왔다.8

손목뼈의 바닥 쪽 활주는 손목뼈 폄을 향상시키기 위해 강조되어 왔다.1,2 열린 또는 닫힌 사슬운동 자세에서 제한된 손목관절 움직임 을 가지고 있는 대상자에게 움직임이 일어나는 방향 쪽으로 도수를 이용해 손목뼈에 지속적인 활주를 동반하는 것이다. 그러나 손목뼈 는 매우작기 때문에 움직임 동안에 도수적으로 손목뼈를 닿는 것은 매우 어렵다. 특히 손을 통한 체중 지지가 이뤄질 때 더욱 어렵게 만 든다. 결과적으로 손을 통해서 체중 지지가 동반될 때 손목뼈를 접 촉하기 위해 좁은 스트랩을 이용했다. 기존의 스트랩을 이용한 바닥 쪽 활주를 적용하는 것(SVGS)보다 손목관절에서 신연이 적용된 상 태에서 스트랩을 이용한 바닥 쪽 활주를 적용하는 것(SVGSD)이 능 동적 그리고 수동적 손목관절 폄과 통증이 유발되는 최대압력이 더 증가될 수 있었다. 이것은 경미한 정도의 손목관절 폄 제한이 있는 대 상자보다 좀 더 손목관절의 관절주머니가 더 탄력성(flexibility)이 감 소한 상태이거나, 더불어 손목관절 폄 근육들이 더 짧은 상태일 때 적용하면 더 효과가 있을 것이라고 생각한다.
이 연구의 결과에 따라 설명 가능한 요소들을 기술하고자 한다. 첫 번째, 스트랩을 이용한 바닥 쪽 활주 운동의 마지막 자세이다. 선행 연구 같은 경우에는 스트랩을 이용해 활주를 적용하였을 때 마지막 자세는 손목관절 폄 $90^{\circ}$ 각도이다. 손배뼈와 반달뼈를 구성하고 있는 부위는 볼록관절면을 이루고 있고, 먼쪽 노뼈와 자뼈를 구성하고 있 는 부위는 오목관절면을 이루고 있다. 볼록과 오목관절면 관점에서 볼 때, 손목관절이 닫힌 사슬 운동으로 진행될 때는 움직이는 관절면 은 오목관절면이다. 굴림과 활주는 모두 손등 쪽으로 같은 방향으로 진행된다고 볼 수 있다. 따라서 기존 연구에서 적용되었던, 스트랩을 이용한 바닥 쪽 활주의 마지막 자세는 노뼈와 자뼈의 굴림과 활주가 손배뼈 위방향 그리고 앞방향으로 이동하게 된다. 결과적으로 마지 막 자세에서는 노뼈와 자뼈가 손배뼈와 반달뼈 위로 올라가기 때문 에 손목관절에서 스트랩이 닿는 부위의 면적이 더 좁아진다. 이때 반 대손을 이용해서 손목관절을 신연하게 되면 이렇게 마지막 자세에서 좁아진 손목관절 공간을 좀 더 확보할 수 있을 것이다. 그 결과로, 스 트랩으로 발생시키는 활주가 더 효과적으로 일어날 수 있다. 선행연 구에서는 닫힌 사슬 운동 자세에서 수동적으로 손목관절 폄을 하는 동안에 손목뼈의 가까운 쪽 정렬 부분에 바닥 쪽 활주 힘을 적용하 여 바닥 쪽 활주가 잘 일어나게 하였다. 지속적인 활주는 손목관절에 가동관절범위를 향상시키고 통증을 감소시키기 위해 적용될 수 있 다.1718 이 연구에서는 손목관절이 반대 손으로 신연된 상태에서 발을 이용한 스트랩을 통해 손배뼈가 바닥 쪽으로 활주가 더욱 적용됨에 따라 손을 통한 체중 지지 동안에 압력은 더 증가했고, 바닥 쪽으로 누르는 동안 노뼈와 가까운 쪽 손목뼈들 사이에서 생길 수 있는 잠재 적인 충돌 또한 감소시켰다.

둘째는, 손목관절의 관절주머니는 탄력성이 감소된 상태일 때는 손목관절 사이에 위치한 손배뼈와 반달뼈와 먼 쪽 노뼈와 자뼈의 사 이의 간격이 좀 더 좁아진 상태라고 볼 수 있다. 선행연구에서는 기존 의 도수를 이용한 전통적인 바닥 쪽 활주를 적용했을 때보다 스트랩 을 이용하여 바닥 쪽 활주를 적용했을 때 수동적 그리고 능동적 손 목관절 폄과 통증이 유발되는 최대압력증가에 통계학적 유의한 효 과를 제공할 수 있었다. ${ }^{8}$ 이 연구에서는 스트랩만 이용한 바닥 쪽 활 주를 적용했을 때보다 손목관절이 신연된 상태에서 같은 바닥 쪽 활 주를 적용하니, 더 큰 효과가 발생된 이유를 보고자 한다. 손배뼈와 반달뼈를 감싸는 관절 주머니가 탄력성이 감소되었을 때, 적절한 신 연을 통해 관절주머니가 서로 반대방향으로 당겨지면서 장력이 발생 했고, 신장효과가 발생된 것으로 보인다. 이러한 관절주머니에서의 장 력 발생은 관절주머니 자체를 늘림으로써 관절이 움직일 때 굴림과 활주가 좀 더 원활하게 발생될 수 있게 해준다. 또한 관절가동범위가 커질수록 관절의 볼록과 오목관절면 관점에 의해서 굴림과 활주를 더 많이 요구하게 되는데, 이때 관절주머니의 탄력성 감소는 관절 가 
동범위의 제한을 가져오게 한다. 따라서 신연을 통해 관절주머니의 탄력성을 증가시켜주면, 관절가동범위가 증가할 수 있는 것이다. 따 라서, 반대쪽 손을 이용해 신연이 적용된 상태에서 스트랩을 이용한 바닥 쪽 활주를 통해 손목 등 쪽 통증이 있는 대상자에게 능동적 그 리고 수동적 폄 각도와 통증이 유발되는 최대압력이 증가되고 손목 등 쪽 통증이 감소됐기 때문에 자가 신연이 적용된 상태에서 스트랩 을 이용한 바닥 쪽 활주가 추천될 만 하다.

셋째, 대부분의 관절주머니 내부에는 윤활액(synovial fluid)이 존 재한다.2,3 이 윤활액이 있음으로써 관절이 움직일 때 관절면 사이에 서 일어날 수 있는 마찰스트레스와 통증이 최소화되면서 관절가동 범위를 기능적으로 사용할 수 있는 것이다. ${ }^{2,3}$ 이때 관절주머니 내부 에 윤활액이 없다면, 관절면은 동작을 만들기 위해 큰 마찰스트레스 를 발생시킬 것이고, 이것이 통증을 유발하게 된다. 이러한 마찰스트 레스와 통증은 관절면 주변에 뼛조각(osteophyte)을 발생시킬 수 있 고, 더 큰 관절가동범위 제한을 유발할 수 있다. ${ }^{2,3}$ 이때 관절주머니에 주어지는 적절한 신연은 관절주머니 내부에 존재하는 윤활액의 순 환증가(circulation)에 기여한다. 결과적으로 더 큰 관절가동범위와 관 절압력에서도 통증과 마찰스트레스를 최소화하는 데 도움을 줄 수 있는 것이다.

이 연구는 몇 가지 제한점이 있다. 첫째, 반대손을 이용해서 발생시 키는 신연의 힘(pulling strength)과 스트랩을 이용해서 발생시키는 활 주의 힘을 측정하지 않았다. 추후 연구에서는 신연과 활주가 적용될 때 발생되는 힘을 측정하여, 효과적인 적용힘에 대한 연구가 필요하 다. 둘째, 중재의 적용 기간이 1 주일에 5 번만의 수행으로 측정되었다. 추후 연구에서는 스트랩을 이용한 운동에 대한 좀 더 긴 기간 동안 의 적용과 장기적인 효과에 대해 연구가 필요하다. 셋째, 반대쪽 손을 이용해서 손목관절을 신연했을 때 손목관절 내부의 벌어지는 간격 에 대한 측정을 하지 않았다. 추후 연구에서는 초음파 등을 이용해서 신연을 통한 손목관절의 벌어짐 거리를 측정하는 것이 필요하다. 넷 째, 대상자 선정에 있어서 손으로 체중 지지를 하였을 때 손등으로 통 증이 있는 대학생만을 실험 대상자로 하였다. 추후 연구에서는 손을 많이 사용하는 작업 근로자를 대상으로 한 연구가 필요하다.

\section{ACKNOWLEDGEMENTS}

본 연구는 한국연구재단 기초과학연구(생애 첫 연구)의 연구비 지원 을 받았음(No. 2017R1C1B5076172).

\section{REFERENCES}

1. Sahrmann SA. Movement system impairment syndromes of the extremities, cervical and thoracic spines-e-book. Elsevier Health Sciences. 2010.

2. Neumann DA. Kinesiology of the musculoskeletal system-e-book: foundations for rehabilitation. Elsevier Health Sciences. 2013.

3. Kisner C, Colby LA. Therapeutic exercise: foundations and techniques. 6th ed. Philadelphia. Fa Davis. 2012.

4. Kendall FP, McCreary EK, Provance PG, et al. Muscles: testing and function, with posture and pain, 5th ed. Philadelphia, Lippincott Williams \& Wilkins. 2005.

5. Maughan RJ, Watson IS, Weir J. Strength and cross-sectional area of human skeletal muscle. J Physiol, 1983;338:37-49.

6. Rettig AC. Athletic injuries of the wrist and hand: part II: overuse injuries of the wrist and traumatic injuries to the hand. Am J Sports Med. 2004;32(1):262-73.

7. Clarkson HM. Musculoskeletal assessment: joint range of motion and manual muscle strength. 2 nd ed. Philadelphia. Lippincott Williams \& Wilkins. 2000.

8. Choung SD, Kwon OY, Park KN et al. Short-term effects of self-mobilization with a strap on pain and range of motion of the wrist joint in patients with dorsal wrist pain when weight bearing through the hand: a case series. Man Ther. 2013;18(6):568-72.

9. Park SJ, Youn PS. The immediate effect of wrist joint mobilization with taping on range of motion, grip strength, spasticity in stroke patients. J Phys Ther Sci. 2017;29(4):187-93.

10.Tal-Akabi A, Rushton A. An investigation to compare the effectiveness of carpal bone mobilisation and neurodynamic mobilisation as methods of treatment for carpal tunnel syndrome. Man Ther 2000;5(4):214-22.

11. Walker MJ. Manual physical therapy examination and intervention of a patient with radial wrist pain: a case report. J Orthop Sports Phys Ther. 2004;34(12):761-9.

12. Hengeveld E, Banks K. Maitland's peripheral manipulation. 4th ed. Oxford, United Kingdom: Butterworth-Heinemann. 2005.

13. Vicenzino B, Paungmali A, Teys P. Mulligan's mobilization-with-movement, positional faults and pain relief: current concepts from a critical review of literature. Man Ther. 2007;12(2):98-108.

14. Cohen J. Statistical power analysis for the behavioral sciences. 2nd ed. Hillsdale, NJ: Lawrence Erlbaum Associates. 1988;20-40.

15. Herrero GP, Tricás Moreno JM, López OL et al. Indirect influence of specific Kalternborn glide mobilizations of the carpal joint on a subject with neurological impairments. Journal of Bodywork and Movement Therapies. 2007;11(4):275-84.

16. Donatelli RA. Orthopaedic physical therapy. 4th ed. St. Louis: Churchill Livingstone. 2010. 